\title{
Professional profile, well-being and job satisfaction among psychologists working in public healthcare services
}

\author{
Perfil profissional, bem-estar e satisfação \\ no trabalho de psicólogos que atuam \\ em serviços de saúde pública
}

\author{
Alline Alves de SOUSA ${ }^{1}$ \\ Marilia Ferreira DELA COLETA ${ }^{1}$
}

\begin{abstract}
Different work environments and working conditions can affect or influence levels of well-being and job satisfaction. This study's aim was to analyze the well-being and job satisfaction of 66 psychologists working in the public healthcare services of two municipal healthcare centers and a federal university. Data were submitted to descriptive, variance and correlation analyses. The results revealed general averages with values close to the scales' midpoints. The analysis of variance among the groups of psychologists working in the three different facilities showed significant differences in levels of satisfaction regarding working conditions and the perception of accomplishment/expressiveness. The satisfaction scales were significantly correlated with the well-being scales. The conclusion is that the results show possible interventions designed to reduce or eliminate negative factors and increase well-being and job satisfaction.
\end{abstract}

Keywords: Health; Psychologists; Public Health; Satisfaction.

\section{Resumo}

Diferentes ambientes e condições de trabalho podem afetar ou influenciar os níveis de bem-estar e satisfação laboral. O interesse deste estudo foi analisar o bem-estar e a satisfação no trabalho de 66 psicólogos atuantes na saúde pública de duas secretarias municipais de saúde e em uma universidade federal. Os dados foram submetidos a estatísticas descritivas, análises de variância e testes de correlação. Com relação às escalas de Bem-Estar e de Satisfação no Trabalho, as médias apresentaram valores próximos do ponto médio. Foram realizadas análises de variância entre as médias dos grupos de psicólogos que atuavam nas três instituições, indicando diferenças quanto à satisfação com as condições de trabalho e quanto à percepção de realização no trabalho. As escalas de satisfação se correlacionaram significativamente com as escalas de bem-estar. Conclui-se que os resultados encontrados mostram possibilidades de intervenções no sentido de melhorar o bem-estar e a satisfação laboral.

Palavras-chave: Saúde; Psicólogos; Saúde Pública; Satisfação.

\section{$\checkmark v \nabla$}

1 Universidade Federal de Uberlândia, Instituto de Psicologia, Programa de Pós-Graduação em Psicologia. Av. Pará, 1720, Campus Umuarama, 2C, 38405-320, Uberlândia, MG, Brasil. Correspondência para/Correspondence to: M.F. DELA COLETA. E-mail: <marilia.coleta@netsite.com.br>. 
Studies addressing well-being in the context of work in contemporary society are increasingly relevant because occupational activity has gradually but rapidly changed and workers are increasingly required to be agile, skilled and have special qualifications. These changes, however, influence the workers' mental health and well-being (Glina \& Rocha, 2010).

According to Paschoal and Tamayo (2008), the concept of Well-Being at Work (WBW) can be applied to diverse occupational contexts and is defined as:

The prevalence of positive emotions at work and a perception that one can express and develop potentialities/abilities at work and achieve life goals. Defined this way, well-being at work includes both affective (emotions and moods) and cognitive aspects (perception of expressiveness and accomplishments) (p.16).

Therefore, this construct includes emotions, moods, perceptions of expressiveness and accomplishment, which implies an inseparable relationship between affective and cognitive aspects in occupational activity. The cognitive aspects mentioned here are extremely important because personal expressiveness is essential for self-fulfillment and personal happiness. Affective aspects, in turn, can be either positive or negative and accrue from experiences that take place at work (Paschoal \& Tamayo, 2008).

Antecedent variables of well-being at work include: personality traits (Dijkstra, Dierendonck, Evers, \& Dreu, 2005); perception of job stability (Kinnunen, Mauno, \& Siltaloppi, 2010); organizational changes (Osthus, 2007); perceptions of employees regarding organization and work (Paschoal, 2008); interpersonal relationships within organizations (Sonnentag, Unger, \& Nägel, 2013), among other variables. The consequent variables of well-being at work are manifested at two levels: individual and organizational and can be exemplified based on the following variables: increased job satisfaction and increased satisfaction in regard to affections and positive behaviors at work (Hecht \& Boies, 2009); increased organizational financial profits that originate from increased productivity and decreased absenteeism (Schulte \& Vainio, 2010), among others.

Job satisfaction is another variable that has been extensively studied by researchers and that presents a correlation with workers' well-being (Spector, 2010). In regard to antecedent variables of occupational satisfaction, in general the following are pointed out: perception of distributive justice (Card, Mas, Moretti, \& Saez, 2010); perception of organizational support (Gottlieb \& Maitland, 2012); and personality traits (Nicodemus, 2012).

Bandeira, Pitta, and Mercier (2000) assert that the job satisfaction of professionals working within mental healthcare is a result of the degree of satisfaction of the professionals in regard to the quality of services provided to patients, their participation in the service, working conditions, and in regard to their relationship within the service. Work satisfaction can be defined as a feeling that results from the interaction of professionals with their values, beliefs and their work environment, which is also a result of the impact the work environment has on the health and well-being of these professionals.

The occupational activity of these professionals is marked by challenges because the psychologist working in the public health sphere faces difficulties related to the need for professional improvement (Goldenberg \& Aguayo, 2007), institutional aspects (Oliveira, Silva, \& Yamamoto, 2007), frustrations and a lack of acknowledgment (Pereira, 2007), as well as difficulties related to the relationships established with the staff (Pombo-deBarros \& Marsden, 2008). These challenges harm the worker's health and well-being (Araújo, 2008). Individual consequences from decreased WBW among psychologists working in the public health sector may manifest physically, psychologically or behaviorally, with the potential to increase stress or depression and decrease the quality of service and/ or negatively affect the service, staff, or ultimately, the patients.

This study's aim was to analyze the wellbeing of psychologists providing psychotherapeutic clinical care in a specific context, in public healthcare 
services. The objectives were to compare the means of answers of groups of psychologists working in three different public facilities in regard to level of well-being and job satisfaction and verify potential correlations between the subscales of satisfaction (quality of services, participation in the service, working conditions, relationships) and scales measuring well-being at work (positive affection, negative affection, achievement/expressiveness).

A literature review of instruments measuring well-being and job satisfaction showed theoretical and methodological adequacy of a scale of wellbeing at work (Paschoal \& Tamayo, 2008) and another measuring job satisfaction among professionals working in mental healthcare services (Bandeira, et al., 2000). The latter was chosen because it was specifically developed for professionals working in public mental healthcare services.

\section{Method}

\section{Participants}

Psychologists working in the public health sector providing psychotherapeutic clinical care in Uberlandia and Araguari (MG), Brazil, participated in this study. Their participation was voluntary, forming a non-random convenience sample because all the individuals who agreed to participate among those who met the inclusion criteria and were available in the services were included in the sample. Table 1 presents a summary of these participants' personal data.

All the psychologists working in the public health service of the city of Araguari were contacted for data collection (group ARI: $N=17$ ), as well as the available professionals working for the Universidade Federal de Uberlândia (group UFU: $N=25$ ); all the professionals agreed to participate. There are approximately 70 psychologists working in these services in the city of Uberlandia and we expected that at least 25 of these would compose the group to be compared to the other two groups. A total of 66 complete questionnaires were considered appropriate for the statistical procedures.
Table 1

Sample's personal data

\begin{tabular}{lcccc}
\hline Variables & $F$ & $\%$ & $M$ & $S D$ \\
\hline Gender & 2 & 3.0 & & \\
Male & 64 & 97.0 & & \\
Female & & & & \\
Marital status & 41 & 62.1 & & \\
Married & 15 & 22.7 & & \\
Single & 7 & 10.6 & & \\
Divorced & 2 & 3.0 & & \\
Stable union & 1 & 1.5 & & \\
Widowed & & & 40.2 & 9.5 \\
Age & & & 10.4 & 8.9 \\
\hline Time working in the service & & & & \\
\hline
\end{tabular}

Note: M: Mean; SD: Standard Deviation.

The participants working for the Health Department in Araguari were found in the following services: Centro de Apoio Especializado (Specialized Support Center), Centro de Apoio ao Dependente Químico (Support Center for the Chemically Dependent), Centro de Atenção Psicossocial (Psychosocial Care Center), Núcleo de Atenção à Saúde Mental (Center for Mental Healthcare) and Pronto Socorro (Emergency Room). Those from UFU worked in the Psychological Clinic of the Instituto de Psicologia (Psychology Institute), the Diretoria de Qualidade de Vida e Saúde do Servidor (Department of Quality of Life and Health of Public Workers), Hospital das Clínicas (Clinical Hospital), and Oficina da Vida (Life Workshop). The participants hired by the Health Department of Uberlândia worked in Unidades de Atendimento Intensivo (Intensive Service Units), Programas de Saúde da Família (Family Health Programs) and Centro de Atenção Especializada (Specialized Support Center). These public healthcare services are directed to patients who voluntarily seek public healthcare units and may or may not be referred to other facilities.

\section{Instruments}

The instrument used to collect data was composed of one questionnaire addressing personal data, such as age, gender, and marital status, and 
one questionnaire addressing professional information, such as academic degree, whether the professional worked individually or with a team, reasons she/he decided to work in the service, how she/he was hired, time working in the service, and whether the professional's background was sufficient to perform his/her job. The instrument also included two scales: one for measuring job satisfaction and another for measuring well-being at work.

The abbreviated version of the Escala de Avaliação de Satisfação da Equipe em Serviços da Saúde Mental - Brasil (SATIS - BR, Scale to Assess Satisfaction of Mental Healthcare Staff), developed by Bandeira et al. (2000), is composed of 32 closed items that compose four scales. Scale 1 refers to the degree of satisfaction professionals enjoy in regard to the quality of services provided to patients (with 10 items and Cronbach's alpha of 0.83). The second scale assesses the degree of satisfaction of professionals in regard to their participation in the service (with 7 items and a Cronbach's alpha of 0.70). The third scale measures the degree of satisfaction of professionals in regard to working conditions (10 items and Cronbach's alpha of 0.77 ), and the fourth scale measures the degree of satisfaction of professionals in regard to relationships within the service (with 3 items and Cronbach's alpha of 0.63). This scale presents moderate internal consistency that may be considered acceptable because it presents an alpha above 0.60 (Tabachnick \& Fidell, 2001).

The internal consistency index Cronbach's alpha of the SATIS - BR's subscales were: satisfaction of professionals in regard to the quality of services provided to patients, with a reliability index Cronbach's alpha of 0.87 ; satisfaction of professionals in regard to their participation in the service, with a reliability index Cronbach's alpha of 0.70; satisfaction of the professionals in regard to the working conditions with Cronbach's alpha of 0.82 , and satisfaction of professionals in regarding to the relationships established in the service with Cronbach's alpha of 0.76 . The index of internal consistency Cronbach's alpha concerning the general satisfaction of the sample of professionals

252 working in mental healthcare services was 0.92 .
The Escala de Bem-Estar no Trabalho (EBET, Scale of Well-Being at Work) developed by Paschoal \& Tamayo (2008) was also used. It is composed of two parts: one refers to affections at work and the other refers to expressiveness/accomplishment achieved at work. The positive affections scale addresses positive emotions and moods at work. It has nine items and originally presented a Cronbach's alpha of 0.93; the negative affection scale addresses negative emotions and moods at work. It has 12 items and presented a reliability index Cronbach's alpha of 0.91 .

The achievement/expressiveness scale refers to the individual's perception that his/her work expresses and develops potentialities/skills and advances the professional in the pursuit of life goals. The scale has nine items and presented a reliability index Cronbach's alpha of 0.88. All the scales are 5-point Likert scales.

The following indexes were found in regard to reliability (index of internal consistency Cronbach's alpha) for the EBET: positive affections with Cronbach's alpha of 0.94; negative affections Cronbach's alpha of 0.92; and achievement/ expressiveness with Cronbach's alpha of 0.89 .

\section{Procedures}

Data were collected in the participants' work places after the Departments of Health of Araguari and Uberlândia (MG), and the deputy rector of the Human Resources at the UFU, authorized the study. The most appropriate time that would not hinder the participants' regular working hours was scheduled in each of the facilities.

At the scheduled time, each interviewee was informed in regard to the study's objectives, the voluntary and confidential nature of their participation, the instrument's characteristics and average duration. In order to comply with ethical requirements and with the guidelines of the National Council of Health regarding research involving human subjects, each participant signed Free and Informed Consent Forms before answering the questionnaires. This study was approved by the 
Institutional Review Board of Universidade Federal de Uberlândia on March 29, 2010 (Protocol n 008/10).

The statistical analysis of quantitative data was performed using the Statistical Package for the Social Sciences (SPSS) for Windows, version 20. Properly coded personal and professionals variables composed the database, as well as the responses to each item of the scales addressing job satisfaction and well-being at work.

Data were submitted to descriptive statistics, analysis of variance (Snedecor's $\mathrm{F}$ distribution) or Student's $t$ test in order to compare the groups, and to correlation tests (Pearson's $r$ ) to verify the relationships among the variables.

\section{Results}

In regard to professional data, most participants $(72.7 \%)$ worked within multidisciplinary teams, entered public service mainly through open competition $(66.7 \%)$, and the motivation for the job was most frequently related to job stability (50.0\%). Academic backgrounds were considered insufficient to practice in public healthcare services by $57.6 \%$ of the participants. In regard to the respondents' academic degrees, most (72.7\%) attended specialization courses.

The analysis of the means of the total sample on the SATIS - BR indicated that, on average, the participants scored between the midpoint 3 (indifference) and 4 (satisfaction) in regard to working in the facility $(M=3.48 ; S D=0.55)$. In regard to the scale, similar results were found such that the psychologists reported "indifference" and "satisfaction" in regard to the quality of services provided to patients (Scale 1: $M=3.64 ; S D=0.63$ ), in regard to their participation in the service (Scale $2: M=3.44 ; S D=0.68$ ), to working conditions (Scale 3: $M=3.28 ; S D=0.72$ ) and in regard to relationships established within the service (Scale 4: $M=3.83 ; S D=0.85$ ).

To better understand these scores, the means in each of the scales' items were analyzed. The following items stood out among those indicating low satisfaction, with general means below the scale's midpoint: satisfaction with salary $(M=2.38$; $S D=1.20)$, benefits $(M=2.24 ; S D=1.20)$, and in regard to the expectation of being promoted $(M=2.86 ; S D=1.10)$. Among the items with greater satisfaction, with means above the scale's average point (3) and close to 4 , which indicates a more positive assessment, the following stood out: the job's degree of responsibility $(M=4.06 ; S D=0.83)$, the job's degree of autonomy $(M=4.06 ; S D=0.89)$ and the possibility of recommending the service to some friend or relative $(M=4.35 ; S D=0.92)$. Table 2 presents the results of the analysis concerning the results obtained on the SATIS - BR.

In analysis regarding the EBET, the computation of the means resulted in: $2.95(S D=0.84)$ for positive affection; 2.13 ( $S D=0.77$ ) for negative affection; and $3.82(S D=0.60)$ for achievement/ expressiveness (Table 3). Considering that the scale's midpoint is 3, the mean of positive affection was close to the scale's midpoint "My work has made me 'moderately' cheerful, willing, happy, excited,

Table 2

Descriptive analysis of the results obtained with Scale to Assess Satisfaction of Mental Healthcare Staff $(N=66)$

\begin{tabular}{lcccc}
\hline Variables & Minimum & Maximum & $M$ & $S D$ \\
\hline SAT 1 & 1.90 & 4.80 & 3.64 & 0.63 \\
SAT 2 & 2.00 & 4.71 & 3.44 & 0.68 \\
SAT 3 & 1.44 & 4.67 & 3.27 & 0.72 \\
SAT 4 & 1.00 & 5.00 & 3.83 & 0.85 \\
Sat general & 1.91 & 4.66 & 3.47 & 0.55 \\
\hline
\end{tabular}

Note: M: Mean; SD: Standard Deviation; SAT 1: Satisfaction with quality of services; SAT 2: Satisfaction with participation in the service; SAT 3: Satisfaction with working conditions; SAT 4: Satisfaction with relationships within the service. Sat general: General satisfaction of the sample of professionals working in mental healthcare services. 
enthusiastic, thrilled, proud and/or peaceful in the last six months"; the mean obtained for negative affection was close to 2 "My work has made me 'a little' nervous, tense, irritated, upset, impatient, angry, annoyed, depressed, frustrated, anxious, worried, and/or bored in the last six months" and the mean concerning achievement/expressiveness at work was close to 4 :

In this job, I "agree" that I reach my potential, develop skills I consider important, perform activities that express my capabilities, gain important rewards, overcome challenges, achieve results I value, advance in goals I established for my life, do what I really like and express the best of me.

When analyzing the means of positive and negative affections and achievement/expressiveness for the three institutional groups, we verified differences in absolute terms. Analysis of variance were performed to verify the significance of differences among the means of groups of psychologists working in the three facilities on each of the scales, which revealed that the means obtained on the EBET among the groups were significantly different in regard to satisfaction with working conditions ( $F=11.46)$, general satisfaction $(F=3.27)$, and in regard to the achievement/ expressiveness scale $(F=4.40)$.

Tukey's test showed that the UDI group differed significantly from the other two, indicating the lowest level of satisfaction with working conditions. The UDI group also presented significantly lower means than the ARI group in regard to general satisfaction and achievement/ expressiveness.

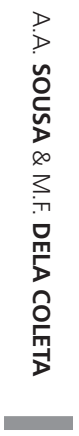

In addition to the differences among the groups, we also tested the differences among

Table 3 subgroups whenever comparisons were possible. Most tests did not show significant differences among the means regarding satisfaction or wellbeing at work, except for those individuals working individually $(M=3.03)$, when compared to those working in multidisciplinary teams; a significantly higher mean was found for the latter $(M=3.56)$ in regard to satisfaction with participation in the service $(t=-2.4 ; p<0.05)$. In regard to the group that believed its background was not sufficient for professional practice, it obtained a significantly higher mean $(M=2.35)$ in regard to negative affection $(t=-3.1 ; p<0.01)$ than the group who believed its background was sufficient $(M=1.82)$.

In order to verify relationships among the scales of satisfaction (quality of services, participation in the service, working conditions, relationships) and the scales concerning well-being at work (positive affection, negative affection, achievement/expressiveness), we computed the correlations (Pearson's $r$ ) among all the measures and found significant correlation coefficients ranging from moderate to high when we correlated the scales for satisfaction with positive affection and satisfaction with achievement, and low correlation in regard to satisfaction with negative affection. Therefore, we verified that the higher the levels of satisfaction, the higher the levels of well-being at work. A high correlation was found between the satisfaction and positive affection scales; that is, the higher the perception concerning high-quality services, the higher the quality of relationships, and the greater the participation in the services and the better the working conditions, the higher is the perception of positive affections at work. Table 4 shows that, in general, the correlations between the general satisfaction scale and the well-being scale were higher than the correlations of each scale for satisfaction with each scale for well-being.

Descriptive data concerning the results obtained on the Scale of Well-Being at Work $(N=66)$

\begin{tabular}{lcccc}
\hline Variables & Minimum & Maximum & $M$ & $S D$ \\
\hline Achievement/Expressiveness & 2.78 & 5.00 & 3.82 & 0.60 \\
Positive affection & 1.22 & 5.00 & 2.95 & 0.84 \\
Negative affection & 1.00 & 4.25 & 2.13 & 0.77 \\
\hline
\end{tabular}

254

Note: M: Mean; SD: Standard Deviation. 
Table 4

Coefficients of correlation (Pearson r) between the scale to assess satisfaction of mental healthcare staff scales and scale of well-being at work scales

\begin{tabular}{|c|c|c|c|c|c|c|c|c|}
\hline Variables & SAT 1 & SAT 2 & SAT 3 & SAT 4 & Sat general & BET 1 & BET 2 & BET 3 \\
\hline SAT 1 & - & $0.52^{*}$ & $0.52^{*}$ & $0.50^{*}$ & $0.83^{*}$ & $0.46^{*}$ & $0.47^{*}$ & $-0.39^{*}$ \\
\hline SAT 2 & & - & $0.47^{*}$ & $0.69^{*}$ & $0.79^{*}$ & $0.58^{*}$ & $0.64^{*}$ & $-0.40^{*}$ \\
\hline SAT 3 & & & - & $0.48^{*}$ & $0.81^{*}$ & $0.52^{*}$ & $0.56^{*}$ & $-0.37^{*}$ \\
\hline SAT 4 & & & & - & $0.74^{*}$ & $0.48^{*}$ & $0.58^{*}$ & $-0.39^{*}$ \\
\hline Sat general & & & & & - & $0.63^{*}$ & $0.69^{*}$ & $-0.48^{*}$ \\
\hline BET 1 & & & & & & - & $0.68^{*}$ & $-0.48^{*}$ \\
\hline BET 2 & & & & & & & - & $-0.49^{*}$ \\
\hline BET 3 & & & & & & & & - \\
\hline
\end{tabular}

Note: * $p<0.01$

SAT 1: Satisfaction with quality of services; SAT 2: Satisfaction with participation in the service; SAT 3: Satisfaction with working conditions; SAT 4: Satisfaction with relationships in the service. Sat general: General satisfaction of the professionals working in the mental healthcare services; BET 1: Fulfillment/expressiveness at work; BET 2: Positive affection; BET 3: Negative affection.

Additionally, we verified relationships among the variables of age, duration of service, and the variables satisfaction and well-being at work. The results show significant correlation only between duration of service and negative affection $(r=-0.24$; $p<0.01$ ), indicating that the longer the psychologists work in the facility, the less negative affection they experience.

\section{Discussion}

The results regarding professional data are very similar to the profile described by Spink (2006): most entered the service through open competition, the existence of multidisciplinary teams, and the reason the professionals chose to work in public healthcare services. Another study conducted with psychologists in Uberlândia by Goya and Rasera (2006) reports that most participants also chose public healthcare services seeking job stability.

In regard to the background of most of the participants with specialization courses, the results were also similar to a study conducted by Spink (2006). According to More, Crepaldi, Queiroz, Wendt, and Cardoso (2004), the increased educational levels of the professionals may reflect the growth in the number of these courses in Brazil in recent decades due to the greater demand coming from the public health sector.
An initial analysis of the results concerning levels of satisfaction revealed that the study participants presented the lowest level of satisfaction in regard to salary and benefits among all the items assessed. In general, studies among psychologists addressing satisfaction with salary have shown a tendency of high levels of dissatisfaction (Rupert, Miller, Hartman, \& Bryant, 2012). In regard to the salary of Brazilin psychologists, which is considered low for the profession (Conselho Federal de Psicologia, 2004), Vasconcelos (2004) states that those working in public healthcare services experience huge inequalities in comparison to other professions. Among the items of the SATIS - BR scale, the highest level of job satisfaction was in regard to job autonomy and responsibility. Chung-Yan (2010) confirms the correlation existing between autonomy and responsibility and job satisfaction.

In regard to the mean levels of satisfaction obtained from this study's participants, we suggest further research comparing work in the public health sector and the profession in general. Two studies conducted with psychologists working in different fields in the region of Triângulo Mineiro $(M G)$, Brazil asked the workers to score their satisfaction with their profession on a scale from zero (dissatisfied) to ten (totally satisfied). The first study, with 118 participants, obtained a mean of 7.9 (Dela Coleta, Marchini, Assunção, \& Rocha, 
2005) and the second (Cunha, Carvalho, \& Dela Coleta, 2006) study conducted with 66 professionals reported a mean of 7.5. Both means are between moderately satisfied and totally satisfied, indicating these individuals were satisfied with their profession.

The analysis of the EBET, in turn, showed that the mean scores obtained by the psychologists were below the midpoint of the negative affection scale, while the scores obtained on the positive affection and achievement/expressiveness scales were above the midpoint of the response scales; the means concerning achievement were the highest. The relationship between affections and the BET was already investigated by Silvério (2008), who reported that positive affections have a greater influence on well-being at work than do negative affections.

The tests of correlation among the study variables indicated important and consistent relationships between the measures of satisfaction and well-being, with coefficients showing moderate correlations in all the cases analyzed. The relationship between satisfaction and well-being at work is found in other studies addressing healthcare professionals (Burke, Moodie, Dolan, \& Fiksenbaum, 2012; Van Horn, Taris, Schaufeli, \& Schreurs, 2004). The analysis of correlations showed few significant results beyond the relationships between satisfaction and BET. Among them is the negative significant correlation between length of time in the field and negative affection. This finding is in agreement with the study conducted by Paschoal (2008), which revealed that among the employees of the same public facility, those with less time of service reported greater negative affection than those who had worked in the facility for longer periods.

Few significant differences were found among the means of the groups in the three facilities. One of the municipal groups presented the lowest satisfaction with working conditions in comparison to the three groups and also significantly lower means in comparison to the other city group in regard to general satisfaction and achievement at work. These differences deserve further investigation at the institutional level, while the most important satisfaction in regard to these items. The changes promoted in this work context should be assessed in terms of efficacy and with a view to promote organizational health (Hernandez, 2007) and quality of services.

Comparing the psychologists working individually and those working within multidisciplinary teams, we verified that the latter presented a significantly higher mean in regard to satisfaction with their participation in their job in comparison to those who worked individually. This finding is in agreement with that reported by Oliveira et al. (2005), who showed that professionals of a Family Health Unit in Natal, Brazil became more satisfied when they started working within multidisciplinary teams. The study conducted by De Marco, Citero, Morais, and Nogueira-Martins (2008) revealed that the participants working in a public psychiatric hospital in São Paulo were more satisfied with teamwork.

Finally, the group who deemed that its background was not sufficient for professional practice (more than half of the participants) obtained a significantly higher mean in Negative Affection than the group who believed its background was sufficient. In this regard, Araújo (2008) verified that the psychologists who perceived deficiencies in their background presented some negative affections such as worry, annoyance, frustration, and nuisance at work.

Various authors among those previously mentioned have addressed the problem regarding the qualification of psychologists and there is concern regarding specific qualifications to work in the public health sector and in multidisciplinary teams (França \& Viana, 2006; Goldenberg \& Aguayo, 2007; Rutsatz \& Câmara, 2006; Mueser, Silverstein, \& Farkas, 2013).

These findings are very similar to those reported by other studies conducted with psychologists in other regions of Brazil, confirming the representativeness of the results found in this study. The participation of psychologists of three public facilities: two at the city level and one from a federal university, was important so that similarities and differences could be observed in regard to the 
professional profiles for the well-being at work and job satisfaction scales.

This study's results suggest a direction for other studies that can support administrative and political decisions to benefit professionals and the quality of services. Therefore, we suggest future studies investigate more deeply the impact of increased well-being among psychologists on the efficiency of services provided in the public health sphere.

These results show possible interventions to decrease or eliminate negative aspects and improve or implement changes related to aspects addressed by both the EBET and the SATIS - BR. In this sense, changes in work organization in institutional sectors are suggested, as well as improved quality of the physical environment and other measures that depend on public policies, such as wages.

\section{References}

Araújo, C. G. A. (2008). A saúde mental está doente! A Síndrome de Burnout em psicólogos que trabalham em Unidades Básicas de Saúde (Dissertação de mestrado não-publicada). Universidade de São Paulo.

Bandeira, M., Pitta, A. M. F., \& Mercier, C. (2000). Escalas Brasileiras de Avaliação da Satisfação (SATIS-BR) e da sobrecarga (IMPACTO-BR) da equipe técnica em serviços de saúde mental. Jornal Brasileiro de Psiquiatria, 49(4), 105-115.

Burke, R. J., Moodie, S., Dolan, S. L., \& Fiksenbaum,L. (2012). Job demands, social support, work satisfaction and psychological well-being among nurses in Spain. Barcelona: ESADE Business School Research Paper.

Card, D., Mas, A., Moretti, E., \& Saez, E. (2010). Inequality at work: The effect of peer salaries on job satisfaction. American Economic Review, 102(6), 2981-3003.

Chung-Yan, G. A. (2010). The nonlinear effects of job complexity and autonomy on job satisfaction, turnover, and psychological well-being. Journal of Occupational Health Psychology, 15(3), 237-251.

Conselho Federal de Psicologia. (2004). Pesquisa traça perfil do psicólogo brasileiro. Recuperado em fevereiro 11, 2011, de http://www.crp07.org.br/noticia.php? $\mathrm{id}=89$

Cunha, T. M., Carvalho, R. F., \& Dela Coleta, M. F. (2006). Avaliação da prática profissional e do perfil de psicólogos que atuam em Uberlândia e região. In IX Encontro Interno e XIII Seminário de Iniciação Científica da UFU. Uberlândia: Universidade Federal de Uberlândia.

De Marco, P. F., Citero, V. A., Moraes, E., \& NogueiraMartins, L. A. (2008). O impacto do trabalho em saúde mental: transtornos psiquiátricos menores, qualidade de vida e satisfação profissional. Jornal Brasileiro de Psiquiatria, 57(3), 178-183.

Dela Coleta, M. F., Marchini, M. M., Assunção, P. F., \& Rocha, D. S. (2005). Estudo preliminar para avaliação do conteúdo pedagógico do curso de Psicologia da UFU em função da demanda atual e futura do mercado de trabalho, para subsidiar projeto de currículo. Uberlândia: Universidade Federal de Uberlândia.

Dijkstra, M. T. M., Dierendonck, D. V., Evers, A., \& Dreu, C. K. D. (2005) Conflict and well-being at work the moderating role of personality. Journal of Managerial Psychology, 20(2), 87-104.

França, A. C. P. de, \& Viana, B. A. (2006). Interface Psicologia e Programa Saúde da Família - PSF: reflexões teóricas. Psicologia Ciência e Profissão, 26(2), 246-257.

Glina, D. M. R., \& Rocha, L. E. (2010). Saúde mental no trabalho: da teoria à prática. São Paulo: Roca.

Goldenberg, J. S., \& Aguayo, M. L. M. (2007). El trabajo de los psicólogos en los centros de atención primaria del sistema público de salud en Chile. Revista Panamericana de Salud Pública, 22(3), 149-59.

Gottlieb, B. H., \& Maitland, S. B. (2012). Take this job and love it: A model of support, job satisfaction, and affective commitment among managers of volunteers. Journal of Community Psychology, 41(1), 65-83.

Goya, A. C. A., \& Rasera, E. F. (2006). A atuação do psicólogo nos serviços públicos de atenção primária à saúde em Uberlândia, MG. In VI Encontro Interno e X Seminário de Iniciação Científica da UFU. Uberlândia: Universidade Federal de Uberlândia.

Hecht, T. D., \& Boies, K. (2009). Structure and correlates of spillover from Nonwork to Work: An examination of nonwork activities, well-being, and work outcomes. Journal of Occupational Health Psychology, 14(4), 414-426.

Hernandez, J. D. (2007). Impactos da percepção de saúde organizacional no bem-estar no trabalho (Dissertação de mestrado não-publicada). Universidade Federal de Uberlândia.

Kinnunen, U., Mauno, S., \& Siltaloppi, M. (2010). Job insecurity, recovery and well-being at work: Recovery experiences as moderators. Economic and Industrial Democracy, 31(2), 179-194.

More, C. L. O. O., Crepaldi, M. A., Queiroz, A. H., Wendt, N. C., \& Cardoso, V. S. (2004). As representações sociais do psicólogo entre os residentes do programa de saúde da família e a importância da interdisciplinaridade. Revista de Psicologia Hospitalar do Hospital das Clínicas, 1(1), 59-75. 
Mueser, K. T., Silverstein, S. M., \& Farkas, M. D. (2013). Should the training of clinical psychologists require competence in the treatment and rehabilitation of individuals with a serious mental illness? Psychiatric Rehabilitation Journal, 36(1), 54-59.

Nicodemus, K. M. (2012). Personality type and job satisfaction. In R. D. Urman \& J. M. Ehrenfeld (Eds.), Physicians' pathways to non-traditional careers and leadership opportunities (pp.11-17). New York: Springer.

Oliveira, I. F. de, Dantas, C. M. B., Costa, A. L. F., Gadelha, T. M. S., Ribeiro, E. M. P. C., \& Yamamoto, O. H. A. (2005). Psicologia, o Sistema Único de Saúde e o Sistema de Informações Ambulatoriais: inovações, propostas e desvirtuamentos. Interação em Psicologia, 9(2), 273-283.

Oliveira, I. F. de, Silva, F. L., \& Yamamoto, O. H. (2007). A psicologia no Programa de Saúde da Família (PSF) em Natal: espaço a ser conquistado ou um limite da prática psicológica? Aletheia, 25, 5-19.

Osthus, S. (2007). For better or worse? Workplace changes and the health and well-being of Norwegian workers. Work, Employment and Society, 21(4), 731-750.

Paschoal, T. (2008). Bem-estar no trabalho: relações com suporte organizacional, prioridades axiológicas e oportunidades de alcance de valores pessoais no trabalho (Tese de Doutorado não-publicada). Universidade de Brasília.

Paschoal, T., \& Tamayo, A. (2008). Construção e validação da Escala de bem-estar no trabalho. Avaliação Psicológica, 7(1), 11-22.

Pereira, P. O. C. (2007). O psicólogo do CAPS: desafios e impasses na construção de uma identidade (Dissertação de mestrado não-publicada), Universidade Federal de Uberlândia.

Pombo-de-Barros, C. F., \& Marsden, M. (2008). Reflexões sobre a prática do psicólogo nos serviços de saúde pública. Arquivos Brasileiros de Psicologia, 60(1), 112-123.

Rupert, P. A., Miller, A. O., Hartman, E. R. T., \& Bryant, F. B.(2012). Predictors of career satisfaction among practicing psychologists. Professional Psychology: Research and Practice, 43(5), 495-502.

Rutsatz, S. N. B., \& Câmara, S. G. (2006). O psicólogo na saúde pública: trajetórias e percepções na conquista desse espaço. Aletheia, 23, 55-64.

Schulte, P., \& Vainio, H. (2010). Well-being at work: Overview and perspective. Scandinavian Journal of Work, Environment \& Health, 36(5), 422-42.

Silvério, W. D. (2008). Experiências afetivas no contexto organizacional e seu impacto sobre o bem-estar no trabalho (Dissertação de mestrado não-publicada). Universidade Metodista de São Paulo, São Bernardo do Campo.

Sonnentag, S., Unger, D., \& Nägel, I. J. (2013). Workplace conflict and employee well-being: The moderating role of detachment from work during off-job time. International Journal of Conflict Management, 24(2), 166-183.

Spector, P. E. (2010). Psicologia nas organizações ( $3^{\mathrm{a}}$ ed.). São Paulo: Saraiva.

Spink, M. J. P. (Coord.). (2006). A Psicologia em diálogo com o SUS: prática profissional e produção acadêmica (Relatório Final). Brasília: Associação Brasileira de Ensino de Psicologia.

Tabachnick, B. G., \& Fidell, L. S. (2001). Using multivariate statistics ( $4^{a}$ ed.). California: Allyn \& Bacon.

Van Horn, J. E., Taris, T. W., Schaufeli, W. B., \& Schreurs, P. J. G. (2004). The structure of occupational wellbeing: A study among Dutch teachers. Journal of Occupational and Organizational Psychology, 77(3), 365-375.

Vasconcelos, E. (2004). Mundos paralelos, até quando? Os psicólogos e o campo da saúde mental pública no Brasil nas duas últimas décadas. Mnemosine, 1, 73-90.

Received: October 17, 2013

Final version: May 7, 2014

Approved: July 14, 2014 